\title{
A NEW GENUS OF GLOSSOPTERID FRUCTIFICATIONS FROM THE ARTINSKIAN TO CHANGHSINGIAN OF EASTERN AUSTRALIA
}

\author{
STEPHEN MCLOUGHLIN
}

Department of Palaeobiology, Swedish Museum of Natural History, Box 50007, SE-104 05 Stockholm, Sweden. steve.mcloughlin@nrm.se

\begin{abstract}
A new genus, Karingbalia is established to accommodate certain eastern Australian glossopterid fertile organs previously assigned to Ottokaria Zeiller emend. Pant et Nautiyal. Karingbalia differs from Ottokaria mainly by the sub-parallel rather than perpendicular orientation of basal peripheral lobes with respect to the receptacle margin. Moreover, Karingbalia ranges from the Artinskian to Changhsingian, whereas Ottokaria sensu stricto is probably confined to the Cisuralian. Two Karingbalia species are recognized: $K$. inglisensis McLoughlin comb. nov. from the Lopingian of the Bowen and Sydney basins; and K. nychumensis sp. nov. from Artinskian-lower Kungurian strata on the Georgetown Inlier. Several additional species of Ottokaria from across Gondwana do not conform precisely to the diagnosis of that genus and their taxonomic reappraisal is proposed.
\end{abstract}

Key words. Glossopteridales. new genus. Karingbalia. reproductive organ. Sydney Basin. Bowen Basin. Permian.

Resumen. Un nuevo género, Karingbalia, se establece para incluir órganos reproductivos de Glossopteridales, previamente asignados a Ottokaria Zeiller emend. Pant et Nautiyal. Karingbalia se diferencia de Ottokaria principalmente por la orientación sub paralela en lugar de perpendicular de los lóbulos periféricos, respecto a las márgenes del receptáculo. Adicionalmente, Karingbalia posee un rango que vas desde el Artinskiano al Changhsingiano, mientras que Ottokaria sensu stricto puede ser restringido al Cisuraliano. Dos especies son reconocidas para Karingbalia: K. inglisensis McLoughlin comb. nov. del Lopingiano de las cuencas de Bowen y Sidney; y K. nychumensis sp. nov. de los estratos del Artinskiano-Kunguriano temprano de Georgetown Inlier. Numerosas especies adicionales de Ottokaria provenientes de Gondwana no concuerdan en forma precisa con la diagnosis del género, y justifican su reevaluación taxonómica.

Palabras clave. Glossopteridales. nuevo género. Karingbalia. órgano reproductivo. Cuenca de Sidney. Cuenca Bowen. Pérmico.

THE biostratigraphic and biogeographic utility of glossopterids has been hindered by the inadequate demarcation of taxa based on dispersed foliar and reproductive organ adpressions. Over 30 genera have been established since 1881 to accommodate glossopterid ovuliferous reproductive organs but many of the criteria used to discriminate between these taxa have been ambiguous, mis-interpreted, inadequate or preservationally controlled. Several genera have been established on subtle differences that are worthy only of specific distinction (Benecke, 1976), some were founded on characters that represent erroneous interpretations of architectural features (Chandra and Surange, 1977; Adendorff et al., 2002; McLoughlin, 2011a, 2012a), and some genera are probably synonymous being based on characters that are only recognizable under certain modes of preservation [e.g., Dictyopteridium Feistmantel ex Zeiller 1902 emend. McLoughlin 1990a (for impressions/compressions) versus Homevaleia Nishida, Pigg, Kudo, and Rigby
2007 (for permineralizations)]. However, there are a few genera (e.g., Plumsteadia and Ottokaria) that are defined on relatively generalized characters (Zeiller, 1902; Rigby, 1978; Pant and Nautiyal, 1984; McLoughlin 1990b; Ryberg 2009; Cariglino et al., 2009). These taxa encompass a broad spectrum of morphologies that can be segregated into several discrete genera.

Ottokaria was one of the earliest-defined genera of glossopterid reproductive organs (Zeiller, 1902), although its connection to Glossopteris/Gangamopteris leaves was not recognized until much later (Plumstead, 1956a; Pant and Nautiyal, 1984; Anderson and Anderson, 1985). The architecture of the organ has been variably interpreted - ranging from a dorsiventrally flattened receptacle rimmed by a lobate wing, to a radially symmetrical seed-bearing 'cob' subtended by a peltate bract (Surange and Chandra, 1975; Rigby, 1978), and even a bivalvate sterile/fertile bract couplet (Plumstead, 1956a; Banerjee, 1978). A unipartite 
dorsiventral organization is now favoured, consistent with that of other ovuliferous glossopterid organs (Adendorff, 2005), but there are striking differences between certain members of the genus with respect to wing lobe orientation that are explored in this study.

Australian ovuliferous glossopterid fructifications have been attributed to around 16 genera in studies extending back to the work of Walkom (1922), with notable contributions by Rigby (1963, 1971, 1972, 1978), White (1964), Holmes (1974, 1990, 1995), Gould and Delevoryas (1977), McLoughlin (1990a, 1990b, 1995, 2012a, 2012b, 2012c) and Nishida et al. (2007). Here I re-evaluate several eastern Australian glossopterid fructifications previously attributed to Ottokaria and note key differences in their wing morphology from the generic type material. These fructifications are, consequently, segregated from Ottokaria as a new genus.

\section{GEOLOGICAL SETTING}

The studied material derives from six lithostratigraphic units in eastern Australia: The Nychum Volcanics (a Permian unit perched on the Precambrian Georgetown Inlier), Black Alley Shale and Burngrove Formation (Bowen Basin), Illawarra and Newcastle coal measures (Sydney Basin), and Black Jack Group (Gunnedah Basin). The lithologies, stratigraphic relationships and fossil floras of these units are outlined briefly here; more detailed discussions of these units were presented by Scheibner and Basden (1998), Donchack et al. (2013) and Champion and Bultitude (2013).

\section{Nychum Volcanics}

The Nychum Volcanics consist predominantly of continental rhyodacitic tuffs intercalated with minor fluvial strata (Morgan, 1974). They are part of the Kennedy Igneous Association (Champion and Bultitude, 2013) that rests unconformably on Paleoproterozoic-Mesoproterozoic rocks of the Georgetown Inlier, and are exposed in small areas of the Nychum district, north of Chillagoe, in north Queensland (Fig. 1.1-2). Although White (in Black et al., 1972) proposed a Pennsylvanian age for this unit based on the occurrence of the Northern Hemisphere taxon Cardiopteris, Balme (1973) and Rigby (1993) pointed out errors in her taxonomic identifications and favoured a Cisuralian age. Bailey et al. (1982) obtained $\mathrm{Rb}-\mathrm{Sr}$ and $\mathrm{K}-\mathrm{Ar}$ dates but with rather broad error bars (270 $\pm 16 \mathrm{Ma}$ : mean of Roadian) from the volcanics, but greater mean ages (277 \pm 4 Ma: late Artinskian - early Kungurian) were obtained by Garrad and Bultitude (1999), and the age of the unit has also been considered to be around 290-280 Ma (early Artinskian - early Kungurian) based on regional stratigraphic correlations (Champion and Bultitude, 2013). The volcanics host a macroflora containing Austroannularia, Paracalamites, Neomariopteris, Bergiopteris, Glossopteris, Noeggerathiopsis and Walkomiella species, together with dispersed seeds and bracts (Black et al., 1972; Rigby, 1993). A single glossopterid reproductive organ that was reported but never figured by Black et al. (1972) or Rigby (1993) is described and illustrated herein.

\section{Black Alley Shale and Burngrove Formation}

The Black Alley Shale and Burngrove Formation are laterally contiguous units consisting of tuffaceous shales and siltstones occurring in the southwestern (Denison Trough) and central (Comet Platform) regions, respectively, of the Bowen Basin, east-central Queensland. Studied specimens from the Black Alley Shale derive from localities L5417 and L5418 on the Inglis Dome (Fig. 1.3), whereas material from the Burngrove Formation derives from Burngrove Creek near Blackwater (Fig. 1.3). These units host rich plant fossil assemblages that were described by McLoughlin (1988, 1992, 1994a, 1994b, 1995). Numerous glossopterid fructifications from the Black Alley Shale originally assigned to Ottokaria inglisensis (McLoughlin, 1990a) are re-examined in this study. A single congeneric specimen is documented from the Burngrove Formation. Both units were deposited in a complex of low-energy lacustrine, paludal and coastal settings during the final stages of marine regression from the Bowen Basin (Fielding et al., 2001; Brakel et al., 2009). The abundant tuffaceous content of both units signifies deposition during the peak phase of Lopingian volcanism in the orogenic belt immediately to the east of the Bowen Basin (Harbort et al., 2001). A Wuchiapingian age has traditionally been attributed to both units based on palynostratigraphy, radiometric dating of ash beds, and regional lithostratigraphic correlations (Price, 1983, 1997; Fielding et al., 2008; Shi et al., 2010; Nicoll et al., 2012). However, the most recent high-precision $\mathrm{U}$-Pb zircon CA-TIMS dates from tuff beds suggest that these units reach ages as young as the early Changhsingian (253.41 $0.11 \mathrm{Ma}$ : Nicoll et al., 2015; Metcalfe et al., 2015). 


\section{Illawarra and Newcastle coal measures}

Studied material derives from exposures of the Illawarra Coal Measures at Widden Valley, northwestern Sydney Basin, and the Newcastle Coal Measures at unspecified localities in the Newcastle district, northeastern Sydney Basin, New South Wales (Fig. 1.4). The Illawarra and Newcastle coal measures were deposited in broad alluvial plain systems hosting extensive glossopterid-dominated mires towards the close of the Permian in the southern to west- ern and northeastern parts of the Sydney Basin, respectively (Agnew et al., 1995; Yoo et al., 1995). These units are richly fossiliferous (Rigby, 1964; White, 1978; Beattie, 2007; Holmes, 1974, 1995) but the fossil floras have not been fully described. Tuffs are sporadically interspersed with the fluvial sediments, resulting in locally strong silicification of some leaf-bearing beds (Pigg and McLoughlin, 1997). The most recent $\mathrm{U}-\mathrm{Pb}$ zircon CA-TIMS dating of these tuffs indicate deposition of the Illawarra Coal Measures extended

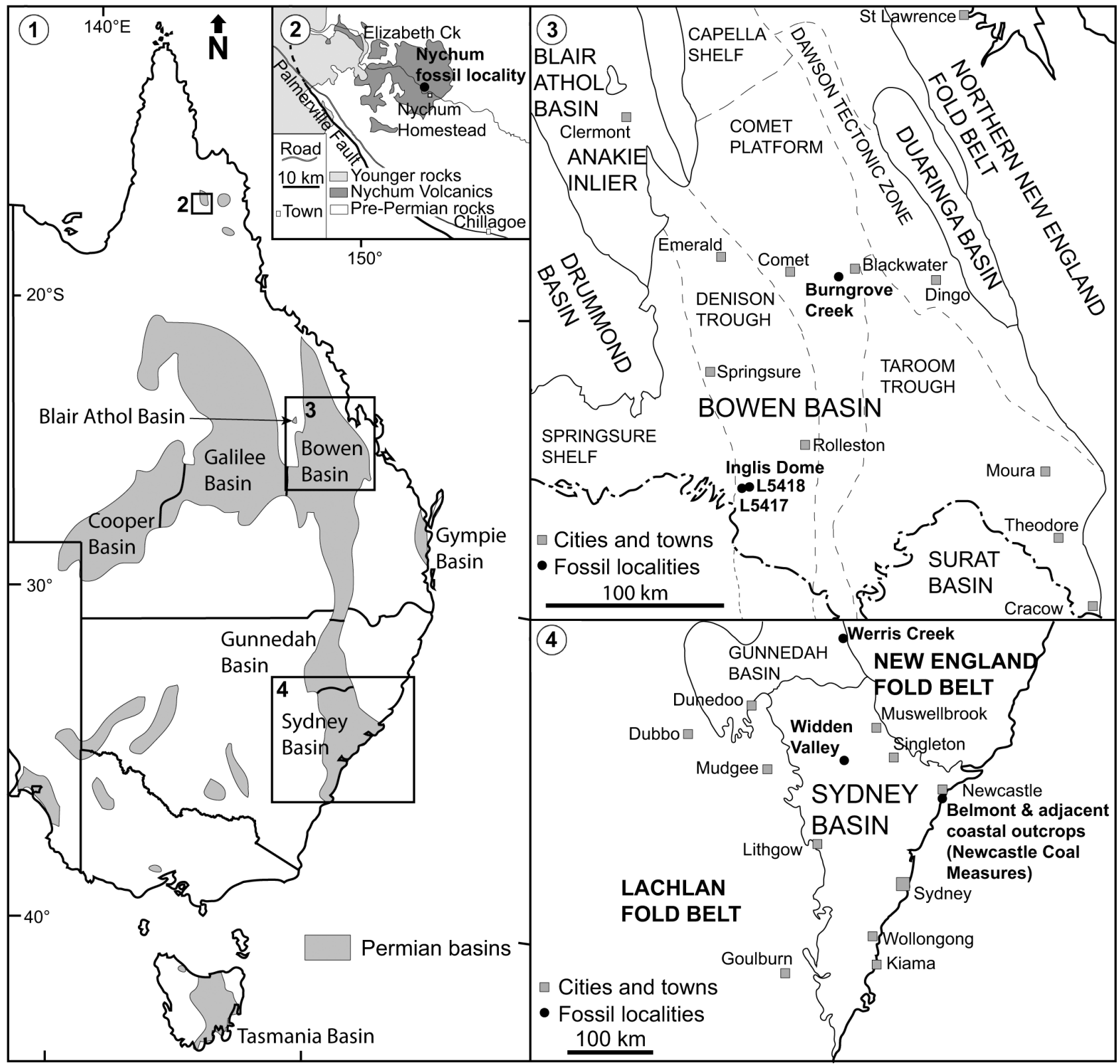

Figure 1. Regional maps showing the distribution of fossil localities. 1, Eastern Australia, showing the distribution of Permian sedimentary basins; 2, Nychum area, Georgetown inlier; 3, Central Bowen Basin; 4, Sydney and southern Gunnedah basins. 
from the early Wuchiapingian to Changhsingian (estimated base of 259.1 Ma to dated top of $252.60 \pm 0.04 \mathrm{Ma}$ ), whereas Metcalfe et al. (2015) indicated accumulation of the Newcastle Coal Measures ranged from the mid-Wuchiapingian (slightly earlier than 255.26 \pm 0.07 Ma measured from the Nobbys Tuff bed) to Changhsingian (slightly younger than $252.78 \pm 0.07$ Ma measured from the Cowper Tuff bed). More refined ages for the eight specimens studied from the Illawarra Coal Measures and the single specimens recovered from the Newcastle Coal Measures and Black Jack Group are not possible owing to uncertainties associated with the precise sampling levels for these historical collections.

\section{Black Jack Group}

A single specimen illustrated by Walkom (1935: pl. 19, fig. 10) derives from strata that he assigned to the Newcastle Coal Measures of the 'Werrie Basin'. These strata are now attributable to the Black Jack Group (?latest Capitanian to Changhsingian) of the Gunnedah Basin (Fig. 1.4) and are mostly correlative with and of equivalent depositional setting to, the Illawarra Coal Measures of the adjacent Sydney Basin (Scheibner and Basden, 1998).

\section{MATERIAL AND METHODS}

All studied specimens are preserved as impressions in fine-grained tuffaceous sediments. Some show marked relief owing to arching or folding of the marginal wing into the host sediment, and this feature, which is common amongst related fertile organs, has led to spurious interpretations of glossopterid reproductive structures in the past, e.g., as bipartite organs (Plumstead, 1956b) or as casts (Rex, 1986). Prevec et al. (2008) and Prevec (2011, 2014) effectively demonstrated variations in preservational style of typical glossopterid fructication impressions and illustrated the range of architectures interpretable from these organs. Specimens were photographed under low-angle unidirectional light using a Canon EOS 40D camera equipped with a macro-lens. Specimens from the Bowen Basin were collected by the author and are held in the collections of the University of Queensland (prefixed UQF), currently administered by the Queensland Museum, Brisbane. Specimens from the Nychum Volcanics were collected during a regional geological survey in the 1960s (de Keyser, 1961) and are held in the collections of Geoscience Australia, Canberra (prefixed CPC). Material from the Sydney Basin was donated to the Australian Museum (prefixed AMF) by undocumented private collectors. The single specimen from the Gunnedah Basin was collected by S.W. Carey (1934) during regional geological mapping and donated and the Geology Department of Sydney University (prefixed SU), Sydney. Other illustrated material is held in the collections of Evolutionary Studies Institute (formerly Bernard Price Institute for Palaeontological Research), University of the Witwatersrand, South Africa (prefixed BP); the Department of Botany, The University of Calcutta (prefixed R.TR), India; and the Geological Survey of India, Calcutta, India (prefixed GSI).

\section{SYSTEMATIC PALEOBOTANY}

Class DictYopteridiopsida Doweld, 2001

Order DictYopteridiales McLoughlin ex Doweld, 2001

Family DictYOPTERIDIACEAE Surange and Chandra ex Rigby, 1978 emend. Maheshwari, 1990

Genus Karingbalia gen. nov.

Type species. Karingbalia inglisensis comb. nov.

Derivation of name. Named for the area occupied by the indigenous Karingbal people around the headwaters of the Comet River in central Queensland (Tindale, 1940), whence the type species derives.

Diagnosis. Glossopterid ovuliferous fructifications consisting of circular, elliptical, obovate or flabellate receptacle bearing $<50$ seed scars, surrounded by a lobate wing in which apical lobes are perpendicular to receptacle margin but basal lobes are aligned sub-parallel to receptacle margin with apices orientated distally.

Discussion. In most aspects of its architecture, Karingbalia is very similar to Ottokaria, but it differs primarily in that the wing lobes are not consistently perpendicular to the receptacle margin; wing lobes are sub-parallel to the margin in the proximal portion of Karingbalia fructifications (Fig. 2.1-2). Wing morphology has been important for differentiating several other glossopterid fructification genera. The upswept wing striations near the base of Karingbalia fructifications are similarly orientated to those of the secondary wing of Bifariala (Prevec et al., 2008) and Elatra (Appert, 
(1)

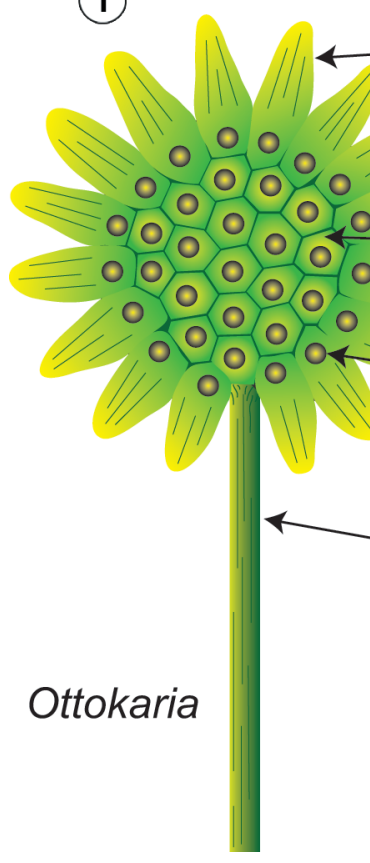

Wing lobes

(2)

Perpendicular

to receptacle throughout

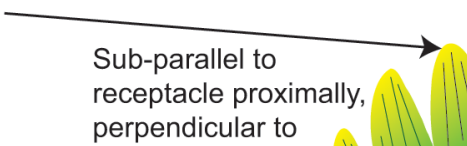
perpendicular to

Generally circular

Receptacle receptacle distally

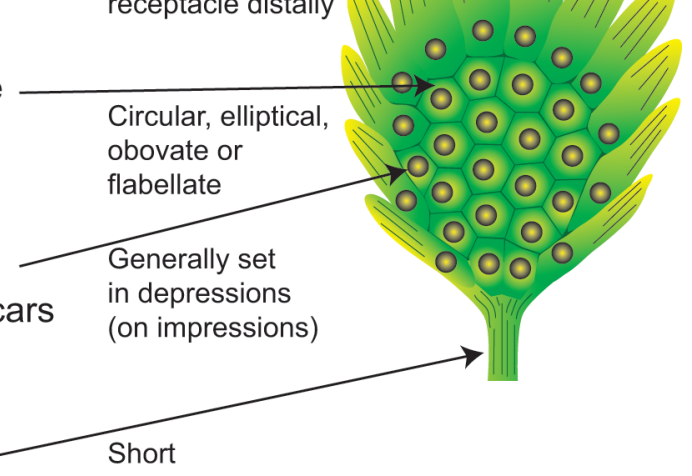

Generally set

on slight mounds

(on impressions)

Seed

detachment scars

(tubercles)

Typically long<smiles></smiles>

\section{Karingbalia}

Figure 2. Schematic diagrams showing the main architectural differences between Ottokaria (1) and Karingbalia (2) fructifications.

1977; Prevec, 2014) and this character may be useful in future efforts to evaluate phylogenetic relationships amongst glossopterids. Bifariala and Elatra differ from Karingbalia in, among other features, that they have a double-winged architecture. Scutum species differ by having margins that may be cusped but never deeply lobed (Prevec, 2011). Karingbalia fructifications tend to possess a short ( $<5 \mathrm{~mm})$ pedicel, whereas species of Ottokaria, including the type species, 0 . bengalensis Zeiller, 1902, more commonly possess very long and slender pedicels (Plumstead, 1956a; Banerjee, 1978; Anderson and Anderson, 1985). Moreover, Ottokaria ovuliferous receptacles tend to be circular with slightly raised seed-scars, whereas those of Karingbalia may be slightly elliptical, obovate or flabellate with generally sunken seed scars (Fig. 2).

\section{Karingbalia inglisensis McLoughlin comb. nov.}

Figure 3.1-11

\section{Synonymy}

?1935 Cone (?Araucarian); Walkom, p. 463, pl. 19, fig. 10.

1978 Rigbya arberioides Lacey et al.; White, pp. 501-502; fig. 71.

1990(a) Ottokaria inglisensis McLoughlin, pp. 22-23; figs. 9, 10; pls. II, 1-5; III, 1-6. [Basionym].

2010 Ottokaria inglisensis McLoughlin; Shi, Waterhouse and McLoughlin, pp. 246, 247; fig. $10 \mathrm{E}$.

Type material. UQF76119a, b (holotype); UQF76070UQF76184 (paratypes); University of Queensland fossil

Figure 3. Karingbalia inglisensis McLoughlin comb. nov.; 1, UQF76126a, mould of fertile surface showing distally swept wing; 2, UQF76093a, mould of fertile surface showing basal wing lobes subparallel to receptacle margin; 3, AMF139730, mould of sterile surface; 4, UQF79449, mould of fertile surface; 5, UQF76119a (holotype), showing details of the tubercular seed scars and fine radiating striae (arrowed); 6 , AMF139729, mould of margin of receptacle sterile surface showing fine hair-like striae surrounding seed scars (arrowed); 7, AMF139726, mould of fertile surface showing prominent striate wing lobes (note proximal lobes in this specimen are twisted owing to oblique compaction); 8, AMF139724, mould of fertile surface; 9, AMF139723, mould of fertile surface; 10, AMF139728 (=counterpart to AMF139726), mould of sterile surface; 11, AMF37390, mould of fertile surface. 1, 2, 5, from locality L5417, Black Alley Shale (Wuchiapingian-early Changhsingian); 3, 6-10, from Widden Valley, Illawarra Coal Measures (Wuchiapingian-Changhsingian); 4, from Burngrove Creek, Burngrove Formation (Wuchiapingian-early Changhsingian); 11, from Newcastle district, Newcastle Coal Measures (mid-Wuchiapingian-Changhsingian). Scale bars $=5 \mathrm{~mm}$ except for 5 and $11(=1 \mathrm{~mm})$. 


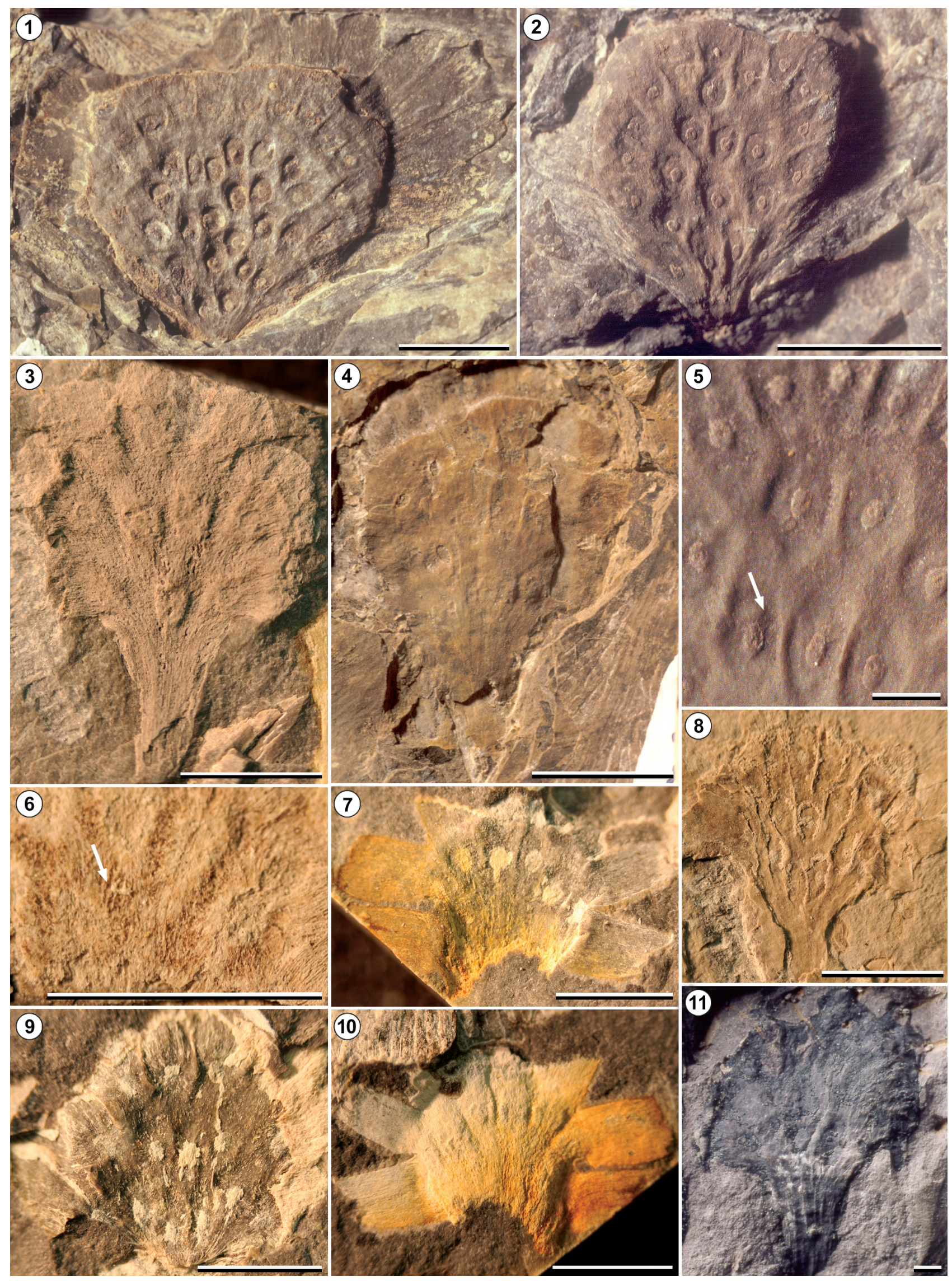


Iocality L5417, tributary of Stony Creek, 48 km west- southwest of Rolleston, east-central Queensland; Black Alley Shale, Blenheim Subgroup; Changhsingian.

Additional material. Burngrove Formation (Burngrove Creek, Bowen Basin, Queensland) - one specimen (UQF79449); Illawarra Coal Measures (Widden Valley, northwestern Sydney Basin, New South Wales) - eight specimens (AMF.139723-F.139730); Newcastle Coal Measures (unspecified localities, Newcastle district, northeastern Sydney Basin, New South Wales) - one specimen (AMF.37390). One specimen equivocally assigned to this species (SU 2044) derives from the Black Jack Group of the southeastern Gunnedah Basin, New South Wales.

Diagnosis and description. See McLoughlin (1990a, pp. 22-23). Remarks. This species was fully described by McLoughlin (1990a) based on material from the southwestern Bowen Basin and the details of the species' circumscription provided in that study remain accurate. An additional specimen from the northwestern Sydney Basin was illustrated by Shi et al. (2010) and new material figured here extends the range of this species into the central Bowen, Gunnedah and northeastern Sydney basins. Initially recovered from the Black Alley Shale at two closely spaced localities (L5417, L5418) on the Inglis Dome in the Denison Trough (Fig. 1.1, 1.3), the species was first assigned to Ottokaria on the basis of its lobed wing (McLoughlin, 1990a). However, the orientation of the basal lobes (Fig. 3.1-2) set it apart from other Ottokaria species and, with the discovery of another form with similar wing architecture described below, this species warrants reassignment to the separate genus Karingbalia. A new specimen recovered from the Burngrove Formation, central Bowen Basin, has partially concealed marginal lobes (Fig. 3.4), but is otherwise sufficiently similar in size, shape and seed scar arrangement to permit assignment to Karingbalia (formerly Ottokaria) inglisensis. Another specimen from the Newcastle Coal Measures (Fig. 3.11) has a concealed wing but otherwise equivalent receptacle features. Walkom (1935, p. 463, pl. 19, fig. 10) described a fragmentary fertile organ from what is now designated the Black Jack Group of the Gunnedah Basin as "Cone (?Araucarian)". This fructification has similarly orientated wing striae and equivalent receptacle characters to $K$. inglisensis but lobing of the wing is not clear from Walkom's (1935) illustration, hence the specimen is ascribed tentatively to $K$. inglisensis. Eight additional specimens from the Illawarra Coal Measures in the northwestern Sydney Basin have well-preserved receptacles and wings (Fig. 3.3, 3.6-10) that are consistent with the morphological circumscription provided by McLoughlin (1990a). Impressions of the fertile surfaces of several specimens show fine, hair-like striations around the tuberculate seed scars (Fig. 3.5-6) that have been noted previously for Antarctic specimens of Plumsteadia (Ryberg, 2009: pl. II.1) and South African specimens of Elatra (Prevec, 2014). These features may correspond to the spongy, mesh-like, cellular network identified around the base of seeds in permineralized Homevaleia fructifications from northeastern Australia (Nishida et al., 2007).

\section{Karingbalia nychumensis sp. nov.}

Figure 4.1-3

\section{Synonymy}

1972 Glossopteris fructification-Scutum sp.; Black et al., p. 191. (unfigured).

1993 Glossopterid fructification; Rigby, p. 244. (unfigured).

Holotype. CPC 27939, Geoscience Australia, Canberra.

Type locality, unit and age. About $3 \mathrm{~km}$ northwest of Nychum

Figure 4. Karingbalia and Ottokaria fructifications. 1-3, Karingbalia nychumensis sp. nov., CPC27939, Nychum Volcanics (Artinskian-early Kungurian), Georgetown Inlier, Queensland; 1, mould of fertile surface showing prominent marginal lobes; 2, oblique view from apex (with lighting from right) highlighting the strongly convex mould of the fertile surface; 3 , enlargement of a portion of the fertile surface showing deeply sunken seed scars. 4, 5, Ottokaria buriadica, Vryheid Formation (late Sakmarian - late Artinskian), Karoo Basin, South Africa; 4, BP/2/13630, mould of sterile surface; 5, BP/2/13639a, mould of fertile surface. 6, Ottokaria raniganjensis, R.TR.12 (holotype), sterile surface of compression with apparently fluted but entire wing; Raniganj Formation (Changhsingian), Raniganj Coalfield, West Bangal, India. 7, Ottokaria sp. of Singh and Shah (1966), GSI21453, mould of ?sterile surface; Sakoa Group (Cisuralian), Madagascar. 8, Ottokaria sp. of White (1978), AMF19713, mould of fertile surface, Newcastle Coal Measures (mid-Wuchiapingian-Changhsingian), Belmont, Sydney Basin. All scale bars $=5 \mathrm{~mm}$ except for 3 (= $1 \mathrm{~mm})$. 


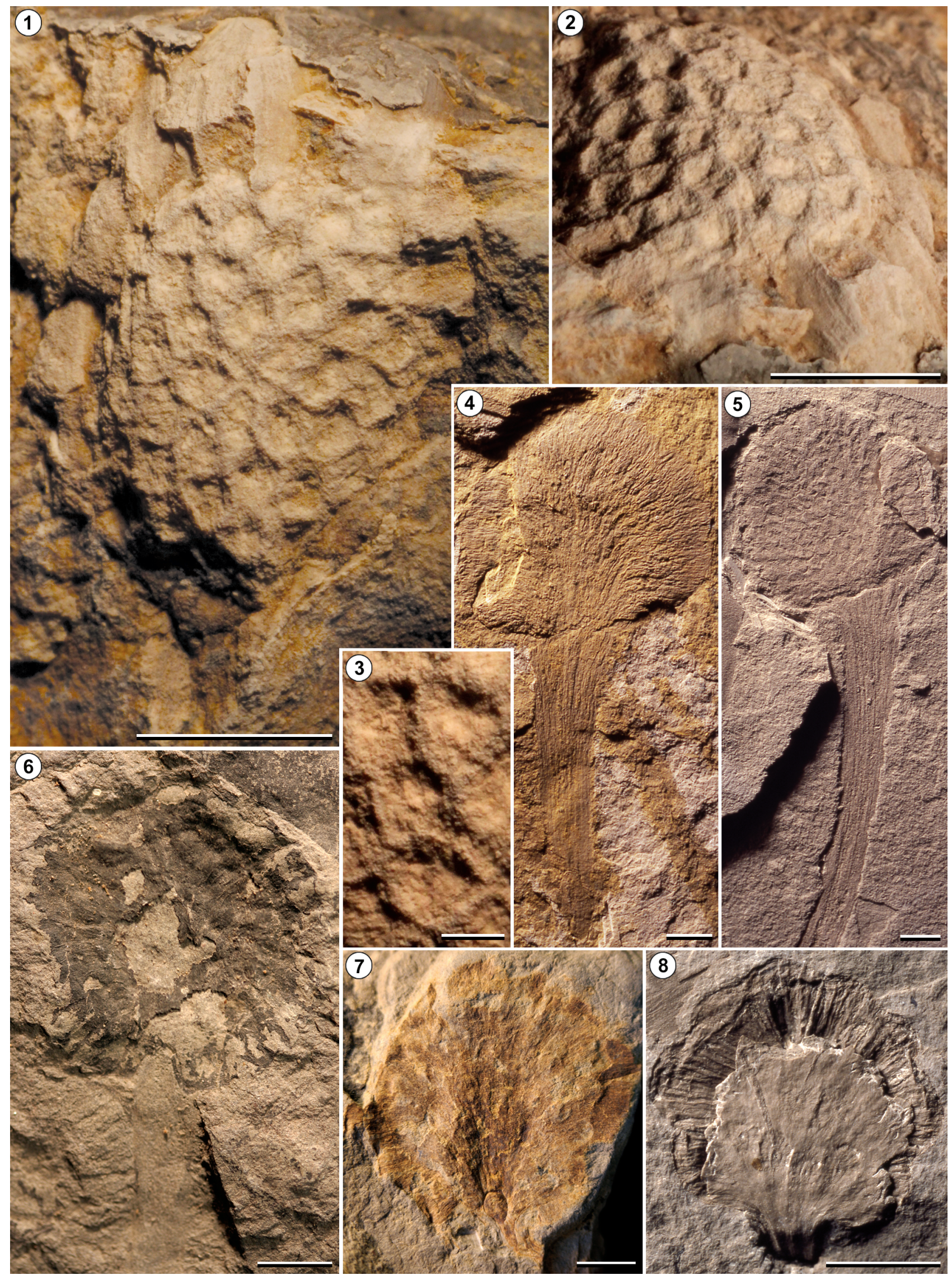


Homestead, near Chillagoe, north Queensland; Nychum Volcanics; Artinskian-early Kungurian.

Etymology. After the type locality.

Diagnosis. Elliptical Karingbalia fructification having deeply sunken seed-cushions with ill-defined central tubercle (vascular supply); wing consisting of lanceolate, apically rounded lobes separated to their bases.

Description. Impression of a single ovuliferous fructification from which all seeds have been shed; lacking counterpart. Receptacle wide-elliptical, $11.5 \mathrm{~mm}$ long, $9 \mathrm{~mm}$ wide (L:W = 1.27), surface strongly arched (convex mould of fertile surface, Fig. 4.2). Receptacle inserted on a short pedicel $3.5 \mathrm{~mm}$ long, $1 \mathrm{~mm}$ wide at base, expanding to $3 \mathrm{~mm}$ wide at merger with receptacle. Receptacle bearing around 40 seed scars in an irregular array (Fig. 4.1). Seed scars (as represented by negative features on impression) consisting of deeply sunken polygonal dimples ca $1 \mathrm{~mm}$ in diameter, bearing an indistinct, central, circular, low tubercle $0.3 \mathrm{~mm}$ in diameter (Fig. 4.3). Ridges between sunken seed scars are $0.3 \mathrm{~mm}$ wide and form a reticulate pattern on the receptacle. Marginal seed scars are flanked by sterile lanceolate flanges that collectively form a lobate wing around the receptacle (Fig. 4.1-2) except for the insertion of the pedicel. Wing lobes up to $3.8 \mathrm{~mm}$ long, $1.5 \mathrm{~mm}$ wide, longitudinally striate, separated to their base; with rounded apices.

Comparisons. This species is represented by a single specimen from the type locality. Although it is normally inadvisable to erect fossil taxa based on solitary specimens because they yield no indication of intraspecific variation, in some groups of organisms, a striking morphology may provide confidence for taxonomic segregation. The specimen from the Nychum Volcanics differs from Karingbalia inglisensis by its more deeply divided wing (lobes separated to the base of the wing), and less distinct tubercles within the seed scars. Karingbalia nychumensis also has a broadly elliptical receptacle whereas that of the type species may be circular, obovate or fan-shaped. White (in Black et al., 1972) attributed this specimen to Scutum but it is excluded from that genus by its deeply lobed wing. Rigby (1993) interpreted this fossil to represent an axially compressed radially symmetrical organ-an interpretation inconsistent with the current understanding of all glossopterid ovuliferous reproductive organs (McLoughlin, 2011b).

\section{DISCUSSION AND CONCLUSIONS Geographic and stratigraphic distribution}

Glossopterid gymnosperms were overwhelmingly dominant through much of middle- to high-latitude Gondwana during the Permian (Anderson et al., 1999; McLoughlin, 2001) and were amongst the major casualties of the mass extinction event at the end of that period (Hill et al., 1999; Vajda \& McLoughlin, 2007). Thus far, all records of the glossopterid fructification Karingbalia are restricted to sedimentary basins within eastern Australia that formed along the convergent Panthalassan margin of southeastern Gondwana. The most similar genus, Ottokaria, has a much broader distribution including Western Australia (McLoughlin, 1995; McLoughlin and McNamara, 2001), India (Banerjee, 1978; Srivastava, 1978; Mukherjee et al., 1966; Pant and Nautiyal, 1984), Madagascar (Singh and Shah, 1966; Appert, 1977), South Africa (Anderson and Anderson, 1985 and references therein), and South America (White, 1908; Menéndez, 1962; Archangelsky and Arrondo, 1969; Dolianiti, 1971; CazzuloKlepzig et al., 1980; Bernardes de Oliveira and de Carvalho, 1981; Bernardes de Oliveira et al., 2000), but convincing examples are not yet known in eastern Australia. Neither genus is yet known from Antarctica. A specimen attributed to Ottokaria from the Sydney Basin by White (1978), lacks distinct marginal lobes and has features consistent with a hooded wing architecture that suggest affinities with Elatra (Prevec, 2014). Thus, Ottokaria and Karingbalia have mutually exclusive palaeogeographic distributions based on currently documented assemblages.

These, and other genera of glossopterid fructifications are potentially useful as biostratigraphic indices (McLoughlin, 1993). Ottokaria has a range that probably initiated in the Asselian based on the occurrence of $O$. kathwaiensis in lowermost Permian strata of the Salt Range, Pakistan (Virkki, 1938; Pant and Nautiyal, 1984). The genus is richly represented in late Sakmarian to Artinskian strata in South America (Bernardes de Oliveira and de Carvalho, 1981; Bernardes de Oliveira et al., 2000), southern Africa (Anderson and Anderson, 1985), Madagascar (Singh and Shah, 1966), India (Pant and Nautiyal, 1984), and Western Australia (McLoughlin, 1995). It becomes less common in younger strata, its last putative representative being $O$. raniganjensis (Banerjee, 1978) from the Raniganj Formation (Lopingian) of India - the only reported Late Permian example of the 
genus (but see comments on this species below). In contrast, Karingbalia is represented by a single specimen from the Artinskian-early Kungurian Nychum Volcanics, and is otherwise known only from ?latest Capitanian-Changhsingian strata. Therefore, the stratigraphic ranges of these genera overlap, but Ottokaria is more typical of Cisuralian strata whereas Karingbalia is most common in the Lopingian.

\section{Equivocal Ottokaria species}

In the course of inspecting specimens potentially attributable to Karingbalia, questions arose concerning the identities of several specimens previously assigned to Ottokaria. Four taxa (re-illustrated here for comparative purposes) are of particular interest: 1, Ottokaria sp. of Singh and Shah (1966; Fig. 4.7); 2, Ottokaria raniganjensis (Fig. 4.6); 3, Ottokaria sp. of White (1978; Fig. 4.8); 4, Ottokaria buriadica (Fig. 4.4-5).

Ottokaria sp. of Singh and Shah (1966) is represented by a single poorly preserved specimen from Cisuralian strata of Madagascar. The specimen has a circular receptacle typical of Ottokaria, but the presence of marginal lobes constituting the wing is equivocal. The wing margin is abraded in most parts, but appears to be entire in the lower left (Fig. 4.7)a feature atypical of Ottokaria. The specimen can not be assigned to Ottokaria unequivocally.

Ottokaria raniganjensis, represented by several specimens from Lopingian strata of northeast India, is by far the youngest example of this genus. Similar to the Madagascan fructification mentioned above, the 0 . raniganjensis specimens have degraded margins but, where preserved, the wing appears to be strongly fluted and entire (Fig. 4.6, lower right of specimen), and perhaps locally cleft by tears rather than being naturally lobed. Its affinities may lie with Scutum or Plumsteadia rather than Ottokaria.

Ottokaria sp. of White (1978), represented by a single eastern Australian specimen (Fig. 4.8), has been discussed by Prevec (2014) who noted striate surfaces both on the counterpart and on a level beneath the impression of the fertile surface suggesting a folded or hooded structure for the wing. Regardless of the arrangement of the wing, it lacks the prominent lobing necessary for assignment to Ottokaria.

Ottokaria buriadica from the Vryheid Formation (late Sakmarian - late Artinskian) of South Africa also lacks the deeply separated wing lobes typical of the genus, although the wing may be finely denticulate apically (Fig. 4.4-5; see also illustrations of Anderson and Anderson, 1985, pl. 56). This species does have a long pedicel (common amongst Ottokaria species) but this feature is also known in some other genera of glossopterid fructifications (Adendorff et al., 2002).

Each of the above cases deserves further analysis based on additional material that might provide better details of the wing, receptacle and pedicel characters. Currently, their taxonomic placement is equivocal and, if transferred to other genera in the future, this will significantly alter the stratigraphic range of Ottokaria, restricting it to the Cisuralian.

\section{ACKNOWLEDGEMENTS}

The following individuals are thanked for providing access to fossil plants in their care: Subir Bera, Manju Banerjee and other staff and students of the palaeobotany laboratory, Botany Department, University of Calcutta; Pradip Sarkar and staff of the Curatorial Division of the Geological Survey of India, Calcutta; Naresh Mehrotra, Rajni Tewari and Deepa Agnihotri of the Birbal Sahni Institute of Palaeobotany, Lucknow; Marion Bamford of the Evolutionary Studies Institute, Johannesburg; Kristin Spring and Andrew Rozefelds, of the Queensland Museum, Brisbane; Ross Pogson of the Australian Museum, Sydney; and John Laurie of Geoscience Australia, Canberra. Financial support by the Swedish Research Council (VR grant 2014-5234) and National Science Foundation (project \#1636625) is gratefully acknowledged.

\section{REFERENCES}

Adendorff, R. 2005. [A revision of the ovuliferous fructifications of glossopterids from the Permian of South Africa. Ph.D. thesis, University of the Witwatersrand, Johannesburg, 241 p. Unpublished.].

Adendorff, R., McLoughlin, S., and Bamford, M.K. 2002. A new genus of ovuliferous glossopterid fruits from South Africa. Palaeontologia africana 38: 1-17.

Agnew, D., Bocking, M., Brown, K., Ives, M., Johnson, D., Howes, M., Preston, B., Rigby, R., Warbrooke, P., and Weber, C.R. 1995. Sydney Basin - Newcastle Coalfield. In: C.R. Ward, H.J. Harrington, C.W. Mallett, and J.W. Beeston (Eds.), Geology of Australian Coal Basins. Geological Society of Australia. Coal Geology Group, Special Publication 1, p. 197-212.

Anderson, J.M., and Anderson, H.M. 1985. Palaeoflora of Southern Africa. Prodromus of South African Megafloras Devonian to Lower Cretaceous. A.A. Balkema, Rotterdam, 416 p.

Anderson, J.M., Anderson, H.M., Archangelsky, S., Bamford, M., Chandra, S., Dettmann, M.E., Hill, R.S., McLoughlin, S., and Rösler, O. 1999. Patterns of Gondwana plant colonisation and diversification. Journal of African Earth Sciences 28: 145-167.

Appert, O. 1977. Die Glossopterisflora der Sakoa in südwest-Madagaskar. Palaeontographica 162B: 1-50.

Archangelsky, S., and Arrondo, O.G. 1969. The Permian tafofloras of Argentina, with some considerations about the presence of 'northern' elements and their possible significance. In: A.J. 
Amos (Ed.), Gondwana Stratigraphy. 1st IUGS Gondwana Symposium, Buenos Aires, 1967, UNESCO, Paris, p. 71-89.

Bailey, J.C., Morgan, W.R., and Black, L.P. 1982. Geochemical and isotopic evidence for the age, orogenic setting and petrogenesis of the Nychum volcanic association, North Queensland. Journal of the Geological Society of Australia 29: 375-393.

Balme, B.E. 1973. Correspondence. 'Age of a mixed CardiopterisGlossopteris flora'. Journal of the Geological Society of Australia 20: 103-104.

Banerjee, M. 1978. Glossopteridean fructifications: 2. On the revision of Ottokaria Zeiller and the ocurrence of 0 . raniganjensis Banerjee from the Raniganj Formation (Upper Permian) of India. Indian Journal of Earth Sciences 5: 129-140.

Beattie, R. 2007. The geological setting and palaeoenvironmental and palaeoecological reconstructions of the Upper Permian insect beds at Belmont, New South Wales, Australia. African Invertebrates 48: 41-57.

Benecke, A.K. 1976. Several new forms of Glossopteris fructifications from the Beaufort Daptocephalus-Zone (Upper Permian) of Natal, South Africa. Palaeontologia africana 19: 97-125.

Bernardes de Oliveira, M.E.C., and de Carvalho, R.G. 1981. Fructificaçoes femininas de glossopteridófitas ola Formação Rio Bonito, Groupo Tubarão, Estado de Santa Catarina, Brasil, /I Congresso Latino-Americano de Paleontologia (Porto Alegre), Anais 1: 181-199.

Bernardes de Oliveira, M.E.B., Ricardi-Branco, F., and Rösler, O. 2000. As estruturas reprodutivas de glossopterídeas na sucessão das tafofloras permianas da bacia do Paraná, Brasil. Revista Universidade de Guarulhos, Geociências V (no. especial): 62-68.

Black, L.P., Morgan, W.R., and White, M.E. 1972. Age of a mixed Cardiopteris-Glossopteris flora from $\mathrm{Rb}-\mathrm{Sr}$ measurements on the Nychum Volcanics, north Queensland. Journal of the Geological Society of Australia 19: 190-191.

Brakel, A.T., Totterdell, J.M., Wells, A.T., and Nicoll, M.G. 2009. Sequence stratigraphy and fill history of the Bowen Basin, Queensland. Australian Journal of Earth Sciences 56: 401-432.

Carey, S.W. 1934. The geological structure of the Werrie Basin. Proceedings of the Linnean Society of New South Wales 59: 351-374.

Cariglino, B., Gutiérrez, P.R., and Manassero, M. 2009. Plumsteadia pedicellata sp. nov.: A new glossopterid fructification from La Golondrina Formation (Guadalupian-Lopingian), Santa Cruz Province, Argentina. Review of Palaeobotany and Palynology 156: 329-336.

Cazzulo-Klepzig, M., Guerra-Sommer, M., and Bossi, G.E. 1980. Revisão fitoestratigraphica do Grupo Itararé no Rio Grande do Sul. 1. Acapamento Velho, Cambaí Grande, Budó e Morro Papaléo. Boletim I.G. Universidade de São Paulo 11: 55-76.

Champion, D.C., and Bultitude, R.J. 2013. Kennedy Igneous Association. In: P.A. Jell (Ed.), Geology of Queensland. Geological Survey of Queensland, Brisbane, p. 473-513.

Chandra, S., and Surange, K.R. 1977. Cuticular studies of the reproductive organs of Glossopteris Part 3-Two new female fructifications-Jambadostrobus and Venustostrobus-borne on Glossopteris leaves. Palaeontographica 164B: 127-152.

de Keyser, F. 1961. [Geology and mineral deposits of the Mossman 1:250,000 sheet area, North Queensland. Records of the Bureau of Mineral Resources, Geology and Geophysics, Australia 1961/110: 1-48. Unpublished.].

Dolianiti, E. 1971. A flora do Gondwana Inferior em Santa Catarina VII-O gênero Ottokaria. Ottokaria santa-catarinae n. sp. Anais da Academia Brasileira de Ciências 43 (Suplemento): 337-342.
Donchak, P.J.T., Purdy, D.J., Withnall, I.W., Blake, P.R., and Jell, P.A. 2013. Chapter 5. New England Orogen. In: P.A. Jell (Ed.), Geology of Queensland. Geological Survey of Queensland, Brisbane, p. 305-472.

Doweld, A.B. 2001. Prosyllabus Tracheophytorum. Tentamen Systematis Plantarum Vascularium (Tracheophytorum). GEOS, Moscow, $200 \mathrm{p}$.

Fielding, C.R., Sliwa, R., Holcombe, R.J., and Jones, A.T. 2001. A new palaeogeographic synthesis for the Bowen, Gunnedah and Sydney basins of eastern Australia. In: K.C. Hill, and T. Bernecker (Eds.), Eastern Australasian Basins Symposium 2001: A Refocused Energy Perspective for the Future. Petroleum Exploration Society of Australia Special Publication 1, Melbourne, 269-278.

Fielding, C.R., Frank, T.D., Birgenheier, L.P., Rygel, M.C., Jones, A.T., and Roberts, J. 2008. Stratigraphic imprint of the Late Paleozoic Ice Age in eastern Australia: A record of alternating glacial and nonglacial climate regime. Journal of the Geological Society 165: $129-140$.

Garrad, P.D., and Bultitude, R.J. 1999. Geology, mining history and mineralisation of the Hodgkinson and Kennedy Provinces, Cairns Region, North Queensland. Queensland Minerals and Energy Review Series, Queensland Geological Survey March 1999: $1-306$.

Gould, R.E., and Delevoryas, T. 1977. The biology of Glossopteris: evidence from petrified seed-bearing and pollen-bearing organs. Alcheringa 1: 387-399.

Harbort, T., Holcombe, R.J., Vasconcelos, P., and Fielding, C.R. 2001. Latest Permian emplacement of the Marlborough Block duplex: the major mountain-building phase of the Hunter-Bowen Orogeny in the northern NEFB. The Specialist Group in Tectonics and Structural Geology Field Conference, Ulverstone, Tasmania. Geological Society of Australia Abstracts Series 64: 77-78.

Hill, R.S., Truswell, E.M., McLoughlin, S., and Dettmann, M.E. 1999. The evolution of the Australian flora: fossil evidence. In: A.E. Orchard (Ed.), Flora of Australia, $2^{\text {nd }}$ Edition, 1 (Introduction). CSIRO, Melbourne, p. 251-320.

Holmes, W.B.K. 1974. On some fructifications of the Glossopteridales from the Upper Permian of New South Wales. Proceedings of the Linnean Society of New South Wales 98: 131-141.

Holmes, W.B.K. 1990. Austroglossa walkomii Holmes, a glossopterid ovulate fructification from the Late Permian of New South Wales. In: J.G. Douglas, and D.C. Christophel (Eds.), Proceedings of the 3rd International Organization of Palaeobotany Conference. A-Z Printers, Melbourne, p. 67-73.

Holmes, W.B.K. 1995. The Late Permian megafossil flora from Cooyal, New South Wales, Australia. In: D.D. Pant (Ed.), Global Environment and Diversification of Plants through Geological Time. Birbal Sahni Centenary Volume. Birbal Sahni Institute of Palaeobotany, Lucknow, p. 123-152.

Lacey, W.S., Van Dijk, D.E., and Gordon-Gray, K.D., 1975. Fossil plants from the Upper Permian in the Mooi River district of Natal, South Africa. Annals of the Natal Museum 22: 349-420.

Maheshwari, H.K. 1990. The glossopterid fructifications: an overview. In: J.G. Douglas and D.C. Christophel (Eds.), Proceedings of the

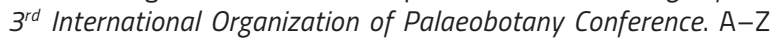
Printers, Melbourne, p. 11-15.

McLoughlin, S. 1988. Geology of the Inglis Dome, Denison Trough, central Queensland. Papers of the Department of Geology, University of Queensland 12: 229-263.

McLoughlin, S. 1990a. Some Permian glossopterid fructifications and leaves from the Bowen Basin, Queensland, Australia. Review of Palaeobotany and Palynology 62: 11-40. 
McLoughlin, S. 1990b. Late Permian glossopterid fructifications from the Bowen and Sydney Basins, eastern Australia. Geobios 23: 283-297.

McLoughlin, S. 1992. Late Permian plant megafossils from the Bowen Basin, Queensland, Australia: Part 1. Palaeontographica 228B: 105-149.

McLoughlin, S. 1993. Glossopterid megafossils in Permian non-marine biostratigraphy. In: R.H. Findlay, H.R. Banks, J.J. Veevers, and R. Unrug (Eds.), Gondwana 8 - Assembly, Evolution, and Dispersal. A.A. Balkema, Rotterdam, p. 253-264.

McLoughlin, S. 1994a. Late Permian plant megafossils from the Bowen Basin, Queensland, Australia: Part 2. Palaeontographica 231B: 1-29.

McLoughlin, S. 1994b. Late Permian plant megafossils from the Bowen Basin, Queensland, Australia: Part 3. Palaeontographica 231B: 31-62.

McLoughlin, S. 1995 Bergiopteris and glossopterid fructifications from the Permian of Western Australia and Queensland. Alcheringa 19: 175-192.

McLoughlin, S. 2001. The breakup history of Gondwana and its impact on pre-Cenozoic floristic provincialism. Australian Journal of Botany 49: 271-300.

McLoughlin, S. 2011a. New records of leaf galls and arthropod oviposition scars in Permian-Triassic Gondwanan gymnosperms. Australian Journal of Botany 59: 156-169.

McLoughlin, S. 2011b. Glossopteris - insights into the architecture and relationships of an iconic Permian Gondwanan plant. Journal of the Botanical Society of Bengal 65: 93-106.

McLoughlin, S. 2012a. The status of Jambadostrobus Chandra and Surange (Glossopteridales). Review of Palaeobotany and Palynology 171: 1-8.

McLoughlin, S. 2012b. Two new Senotheca (Glossopteridales) species from the Sydney Basin, Australia, and a review of the genus. Review of Palaeobotany and Palynology 171: 140-151.

McLoughlin, S. 2012c. Nogoa nom. nov., a replacement name for Cometia McLoughlin. Alcheringa 36: 279-281.

McLoughlin, S., and McNamara, K. 2001. Ancient Floras of Western Australia. Publication of the Department of Earth and Planetary Sciences, Western Australian Museum, 42 p.

Menéndez, C.A. 1962. Hallazgo de una fructificación en la Flora de Glossopteris de la provincia de Buenos Aires (Lanceolatus bonariensis sp. nov.). Con consideraciones sobre la nomenclatura de fructificaciones de Glossopteris. Ameghiniana 2: 175-182.

Metcalfe, I., Crowley, J., Nicoll, R.S., and Schmitz, M. 2015. Highprecision $\mathrm{U}-\mathrm{Pb}$ CA-TIMS calibration of Middle Permian to Lower Triassic sequences, mass extinction and extreme climate-change in eastern Australian Gondwana. Gondwana Research 28: 61-81.

Morgan, W.R. 1974. A Carboniferous continental andesite-rhyolite association from the "Nychum" area, north Queensland, Australia. Journal of Petrology 15: 97-112.

Mukherjee, S., Banerjee, M., and Sen, J. 1966. Further glossopterid fructifications from India. Palaeontographica 117B: 99-113.

Nicoll, R.S., Metcalfe, I., Crowley, J., Ives, M., and Laurie, J.R. 2012. Using high precision CA-IDTIMS zircon age determinations to interpret correlation and depositional rates in Permian coal sediments of the Sydney, Gunnedah and Bowen Basins. 34 ${ }^{\text {th }}$ International Geological Congress, (Brisbane), Abstracts: CD-ROM. Brisbane.

Nicoll, R.S., McKellar, J., Areeba Ayaz, S., Laurie, J., Esterle, J., Crowley, J., Wood, G., and Bodorkos, S. 2015. CA-IDTIMS dating of tuffs, calibration of palynostratigraphy and stratigraphy of the Bowen and Galilee basins. In: J.W. Beeston (Ed.), Bowen Basin Symposium 2015: Bowen Basin and beyond. Geological Society of Australia Coal Geology Group, Hornsby, p. 211-218.

Nishida, H., Pigg, K.B., Kudo, K., and Rigby, J.F. 2007. New evidence of reproductive organs of Glossopteris based on permineralized fossils from Queensland, Australia. I. Ovulate organ Homevaleia gen. nov. Journal of Plant Research 120: 539-549.

Pant, D.D., and Nautiyal, D.D. 1984. On the morphology and structure of Ottokaria zeillerisp. nov. -a female fructification of Glossopteris. Palaeontographica 193B: 127-152.

Pigg, K.B., and McLoughlin, S. 1997. Anatomically preserved Glossopteris leaves from the Bowen and Sydney basins, Australia. Review of Palaeobotany and Palynology 97: 339-359.

Plumstead, E.P. 1956a. On Ottokaria, the fructification of Gangamopteris. Transactions and Proceedings of the Geological Society of South Africa 59: 211-236.

Plumstead, E.P., 1956b. Bisexual fructifications borne on Glossopteris leaves from South Africa. Palaeontographica 100B: 1-25.

Prevec, R. 2011. A structural re-interpretation and revision of the type material of the glossopterid ovuliferous fructification Scutum from South Africa. Palaeontologia africana 46: 1-19.

Prevec, R. 2014. Elatra: a glossopterid fructification with a bipartite, hooded wing from the lower Permian of Madagascar and South Africa. Review of Palaeobotany and Palynology 210: 119-139.

Prevec, R., McLoughlin, S., and Bamford, M.K. 2008. Novel wing morphology revealed in a South African ovuliferous glossopterid fructification. Review of Palaeobotany and Palynology 150: 22-36.

Price, P.L. 1983. A Permian palynostratigraphy for Queensland. In: anonymous (Ed.), Proceedings of the Symposium on the Permian Geology of Queensland. Geological Society of Australia, Queensland Division, Brisbane, p. 155-212.

Price, P.L. 1997. Permian to Jurassic palynostratigraphic nomenclature of the Bowen and Surat Basins. In: P.M. Green (Ed.), The Surat and Bowen Basins, south-east Queensland. Queensland Minerals and Energy Review Series, Queensland Geological Survey, Brisbane, p. 137-178.

Rex, G.M. 1986. Experimental modelling as an aid to interpreting the original three-dimensional structures of compressions. In: R.A. Spicer, and B.A. Thomas (Eds.), Systematic and Taxonomic Approaches in Palaeobotany. The Systematic Association Special Volume 31. Clarendon Press, Oxford, p. 17-36.

Rigby, J.F. 1963. On a collection of plants of Permian age from Baralaba, Queensland. Proceedings of the Linnean Society of New South Wales 87: 341-351.

Rigby, J.F. 1964. The Lower Gondwana flora of the Illawarra Coal Measures, Wollongong, New South Wales, Australia. Report of the Twenty-Second Session, International Geological Congress, New Delhi, 9: 17-25.

Rigby, J.F. 1971. Some palaeobotanical observations concerning the Bowen Basin. Proceedings of the Second Bowen Basin Symposium. Geological Survey of Queensland Report 62: 21-29.

Rigby, J.F. 1972. The flora of the Kaloola Member of the Baralaba Coal Measures, central Queensland. Geological Survey of Queensland Publication 352, Palaeontological Paper 26: 1-12.

Rigby, J.F. 1978. Permian glossopterid and other cycadopsid fructifications from Queensland. Geological Survey of Queensland Publication 367, Palaeontological Paper 41: 1-21.

Rigby, J.F. 1993. Review of the Early Permian flora of the Nychum Volcanics north of Chillagoe, north Queensland. In: R.H. Find- 
Iay, R. Unrug, M.R. Banks, and Veevers, J.J. (Eds.), Gondwana Eight: assembly, evolution and dispersal. A.A. Balkema, Rotterdam, p. 241-247.

Ryberg, P.E. 2009. Reproductive diversity of Antarctic glossopterid seed-ferns. Review of Palaeobotany and Palynology 158: 167179.

Scheibner, E., and Basden, H. 1998. Geology of New South Wales Synthesis. Volume 2 Geological Evolution. Geological Survey of New South Wales Memoir, Geology 13(2), 666 p.

Shi, G.R., Waterhouse, J.B., and McLoughlin, S. 2010. The Lopingian of Australasia: a review of biostratigraphy, correlations, palaeogeography and palaeobiogeography. Geological Journal 45: 230-263.

Singh, G., and Shah, S.C. 1966. Fossil plants from the Sakoa Series, Madagascar. Comptes Rendus de la Semaine Geologique de Madagascar 1966: 17-19.

Srivastava, A.K. 1978. Studies in the Glossopteris flora of India-43. Some new plant fossils from the lower Gondwana sediments of Auranga Coalfield, Bihar. Palaeobotanist 25: 486-495.

Surange, K.R., and Chandra, S. 1975. Morphology of the gymnospermous fructifications of the Glossopteris flora and their relationships. Palaeontographica 149B: 153-180.

Tindale, N.B., 1940. Distribution of Australian Aboriginal tribes: a field survey. Transactions of the Royal Society of South Australia 64: 140-231.

Vajda, V., and McLoughlin, S. 2007. Extinction and recovery patterns of the vegetation across the Cretaceous-Palaeogene boundary-a tool for unravelling the causes of the end-Permian mass-extinction. Review of Palaeobotany and Palynology 144 : 99-112.

Virkki, C. 1938. A Lower Gondwana flora of the Salt Range, Punjab. Proceedings of the $25^{\text {th }}$ Indian Science Congress (Calcutta) Abstracts: $150-151$.

Walkom, A.B. 1922. Palaeozoic floras of Queensland. part 1. The flora of the Lower and Upper Bowen Series. Geological Survey of Queensland Publication 270: 1-65.
Walkom, A.B. 1935. Some fossil seeds from the Palaeozoic rocks of the Werrie Basin. Proceedings of the Linnean Society of New South Wales 88: 392-396.

White, D. 1908. Report on the fossil flora of the coal measures of Brazil. Relatório final Comissão de Estudos das Minas de Carvão de Pedra do Brazil. Imprensa Nacional, Rio de Janeiro 3: 336-617.

White, M.E. 1964. Reproductive structures in Australian Upper Permian Glossopteridae. Proceedings of the Linnean Society of New South Wales 88: 392-396.

White, M.E. 1978. Reproductive structures of the Glossopteridales in the Australian Museum. Records of the Australian Museum 31: 473-504.

Yoo, E.K., Norman, A., and McDonald, I. 1995. Sydney Basin-Western Coalfied. In: C.R. Ward, H.J. Harrington, C.W. Mallett, and J.W. Beeston (Eds.), Geology of Australian Coal Basins. Geological Society of Australia, Coal Geology Group, Special Publication 1, Sydney, p. 231-245.

Zeiller, R. 1902. Observations sur quelques plantes fossiles des Lower Gondwanas. Memoirs of the Geological Survey of India, Palaeontologia Indica N.S. 2: 1-40.

doi: 10.5710/AMGH.09.07.2016.3010

Submitted: April $7^{\text {th }}, 2016$

Accepted: July $9^{\text {th }}, 2016$ 